\title{
Enhancing Students' Deep Approaches to Learning Among Industrial Mechatronics Engineering Technology Students
}

\author{
Norsyarizan Shahria* ${ }^{*}$ Roselainy Abdul Rahman ${ }^{b}$, Noor Hamizah Hussain ${ }^{b}$ \\ ${ }^{a}$ Kolej Kemahiran Tinggi Mara, Genting, 11000 Balik Pulau, Pulau Pinang, Malaysia \\ ${ }^{b}$ UTM Razak School of Engineering and Advanced Technology, Universiti Teknologi Malaysia, 54100, Kuala Lumpur, Malaysia
}

*Corresponding author: norsyarizan@kktmbp.edu.my

\begin{abstract}
Identification of students learning approaches and its characteristics that contribute to learning success are so important in achieving learning outcomes. A previous study has shown that most of the students use more of surface learning approach instead of deep learning approach in their studies. The study uses a questionnaire, R-SPQ-2F to evaluate students' surface and deep learning approach. This paper will present findings from a study that was carried out to compare the effect of using cooperative learning and the traditional method among students in Industrial Mechatronics Engineering Technology Program at MARA High Skill College Balik Pulau, Penang, Malaysia. The aim is to investigate the effectiveness of each method. Using a quantitative approach, two groups of students, one group from each respective teaching method, were studied. Analysis of the findings found that using cooperative learning has a more positive effect when compared to the traditional learning.
\end{abstract}

Keywords: Cooperative learning; traditional learning; surface learning approach; deep learning approach

(C) 2017 Penerbit UTM Press. All rights reserved

\subsection{INTRODUCTION}

In the learning of Programmable Logic Controller (PLC), its concepts and applications are needed in almost every discipline of industrial mechatronics engineering technology program (Shari et al., 2014). It is not only a fundamental prerequisite for subsequent courses such as automation system, production system, mechatronic system design and control system; but it is a crucial course applied in the process of implementing proposal and project in the final year that emphasize on industrial automation system. Thus, it is important for students to understand the concepts and be able to apply the knowledge. The biggest problem for the novice programmer is that they do not understand the basic concepts and therefore cannot apply them. Other difficulties include not having enough resources, lack of personalized instruction to help students with particular difficulties as well as having a large number of students in class with a wide range of abilities. Up to date, students' final examination result does not show good achievement.

PLC is taught in the Industrial Mechatronics Diploma Program in Kolej Kemahiran Tinggi MARA. The teaching method and learning approach for Diploma program at KKTM that has been usually implemented uses the traditional approach which emphasizes direct instruction and lecture, seatwork and students learning through listening and observation. The teaching and assessment methods often encourage students' learning using a surface approach when they are not aligned to the outcomes of the course as the questions are usually routine or slight variations of questions fielded in the lectures. The presence of widespread and frequent use of surface learning approach among students signals that there is a need to review the teaching and the assessment methods. The approaches that prevail tell us something about the quality of the teaching environment that needs to be taken into consideration (Shuelll, 1986). It is important to remember that what the students' do are more important that what the teacher does (Heikkila, 2011).

Students are expected to achieve various learning outcomes that include understanding and ability to apply knowledge and facility with soft skills that will enhance employability. Students are less likely to become independent learners if the lecturer give them all the information on a topic and then interpret and analyze it for them (Ramsden \& Moses, 1992). Towards achieving these outcomes, implementation of group work activity is important so as to ensure students are well-equipped with the necessary social and communication skills to fulfill industrial needs (Shaari \& Jusoh, 2012). Therefore, it is necessary to understand the needs of a pedagogy that can support students' meaningful learning as well as achieve the cognitive and soft skills attainment outcomes (Rowley, 2014; Jacobs et al., 2014).

In an earlier preliminary case study, from the total number of students in year 1 and $2,56 \%$ of students use surface learning approach whereby only $44 \%$ applied the deep learning approach and there was no significant difference between years of study and learning approaches (Shahri \& Jusoh, 2014). The instrument used was R-SPQ-2F questionnaire which can determine students study process either surface or deep learning and determine the motivation and strategy as well during their learning process (John Biggs, 2001).

The term 'approach to learning' originally referred to how intentions and processes were combined in students' learning (Ramsden \& Moses, 1992; Heikkila et al., 2011). It is necessary to guide students towards deep learning approach in order to become mastery oriented learner that is definitely not in surface learning approach. 
Furthermore, factors like intention, interest and strategy are affecting most engineering students' performance but lack of consistency in the findings highlights the need for more in-depth analysis of the effect of learning strategies on academic performance (Aini Nazura Paimin, 2013).

\subsection{LITERATURE REVIEW}

Many researches has shown that using cooperative learning has successfully increased students' achievement and development of generic skills such as motivation to learn, interaction and positive interdependence, adaption of basic skills such as leadership, decision making skill, teamwork, tolerance among group members and improve critical thinking skill (Johnson, 2010). Five criteria must be met, namely, positive interdependent, responsibility, face to face interaction, the usage of interpersonal skill and self-efficacy towards team goal (Felder and Brent, 2004). These criteria become fundamental to cooperative learning planning and administration that has been recognized as proving to give a positive effect on students learning.

Furthermore, cooperative learning can also increase team work ability, problem solving skill, effective information retention and communication skill (Felder and Brent, 2004). Discussion is a key aspect of student learning experience in cooperative learning and students, who have a deep understanding of how the discussions are related to their learning outcomes, tend to approach the discussions in more meaningful ways (Ellis \& Calva, 2004). The method has also been known to be effective in increasing motivation, cognitive development and cognitive expansion (Bonwell \& Eison, 1991). All these effects will encourage towards more positive quality approaches to teaching so as to improve students' learning (Prosser \& Trigwell, 2001).

There are various approaches in cooperative learning which an educator has to explore and investigate their effectiveness in the learning process. Some of these techniques are; controversial development (Johnson \& Johnson, 1993), Jigsaw protocol (Aronson, 1978), Instructional of group acceleration (Slavin \& Kerweit, 1985) and Cooperative learning structure (Spencer Kagan, 2009). Jigsaw technique which is based on specific procedure has a positive impact to students' achievement (Johnson et al., 2000). Jigsaw technique is a complex structure that needs a commitment from students, lecturer and it is also need a proper planning (Felder \& Brent, 2004) and as same as cooperative learning method, a group of such as variation in group, group target or positive interdependence, supportive interaction, individual responsibility, interpersonal skill, equal success chance and group compete.

\subsection{THE STUDY}

\section{Objectives of Study}

In view of students' preference for surface learning, an effort to investigate the possibility of supporting students' to use more deep learning approach was carried out. A class of students was to be taught using cooperative learning methods and their performance will be compared to another class taught using the traditional method. In particular, the jigsaw technique in cooperative learning will be used.

The objective of the study is to identify whether there is any significant relationship between the Jigsaw learning technique and conventional learning technique with students score in the middle semester test and final semester examination in PLC \& automation course among students in Industrial Mechatronic Engineering Technology Program in KKTM. The score can be positive improvement, static and deteriorating of performance. The findings will be used to determine the relationship between students' approach to learning with the successful achievement in Programming Courses and this will be discussed in future work. The following Research Questions guided this study:

RQ1: Are there any significant relationship between Jigsaw learning technique and conventional learning technique with students score in middle semester test and final semester examination.

RQ2: What are students' approaches to learning in Programmable Logic Controller Course (HFC 3042) with regards to deep learning approach after going through those techniques?

Methodology

This research was undertaken for the course HFC 3042 in the third semester 2013/2014 sessions by using a quasi-experimental method and it was divided into two phases. The first phase took fourteen weeks and during that time all students went through traditional methods of learning. At the end of week fourteen, all students were given a brief explanation about the jigsaw technique and were provided with revision material. The students were given an option to choose which learning method to follow. In the second phase, students who chose cooperative learning were given information about their revision class by using the jigsaw technique and in week sixteen, this group of students carried out a presentation.

Those groups who chose conventional learning method proceeded with their revision class on their own. Comparison was also made to other courses which the same students took but performed fully using conventional learning method. Students also need to answer R-SPQ$2 \mathrm{~F}$ questionnaire at the beginning of the semester and after the last meeting session at the end of the semester. The R-SPQ-2F, the Revised Two Factor Study Process Questionnaire is designed to help evaluate students' surface and deep learning approach.

Suitable null and alternate hypotheses were set up, that is:

H0: $\quad$ There is no difference in mean of deep learning approach scores between pre-test or post-test.

H1: There is a difference in mean of deep learning approach scores between pre-test or post-test. 


\section{Research Sample}

The research sample consisted of 61 students from Industrial Mechatronics Engineering Technology Diploma Program who took PLC \& automation course in KKTM Penang, Malaysia. The students' background was nearly homogenous as the majority was male with similar entry qualifications to the program. These students were then divided into two groups A and B. 31 students chose to study with the Jigsaw method and designated as group A while the other 30 students chose the traditional method and were in group B.

The structure of the jigsaw technique used in this research consisted of two groups; jigsaw and expert group. Each student in a jigsaw group has his own expertise according to the topics given by lecturer. Students in their expert group will have discussion and try to understand the topics given among them. After each member in the expert group understand the topics then these students will go back to their jigsaw group and will explain the topics to their teammates. The expert group is formed to encourage students to be empowered in learning the concepts and enable them to think out suitable teaching strategy then teach the concepts to other students in their jigsaw group. Group A then were divided into jigsaw and expert group. There are five expert groups with five topics as follows; basic digital logic programming, timer operation, counter and comparator operation, sequent control system and analog value processing.

\subsection{RESULTS AND DISCUSSION}

\section{Academic Performance Result}

Figure 1 shows the analysis for students' achievement in Group A and B for the difference between middle semester test result and final semester examination result. Details are described in Table 1. Result clearly shows that percentage of marks increment in group A which used the jigsaw technique is very high which is $87 \%$ as compared to the group studying with traditional method with $33.3 \%$.

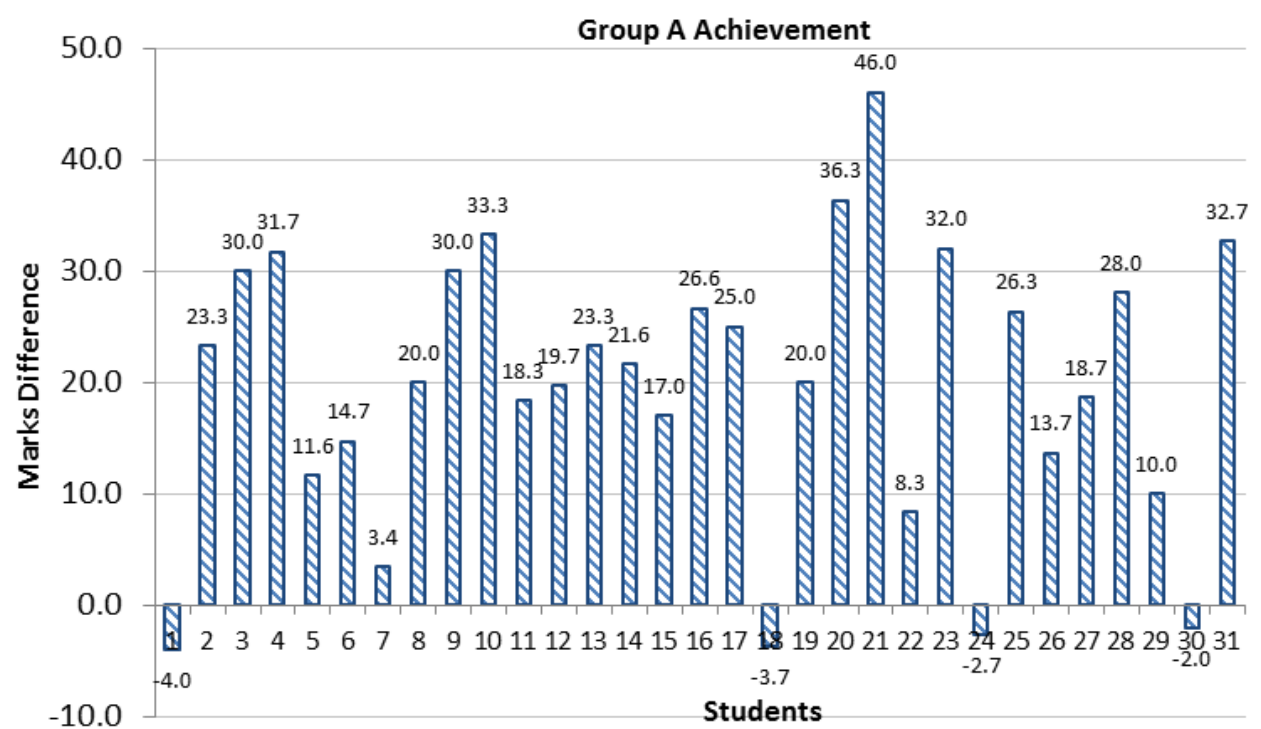

Figure 1(a) 


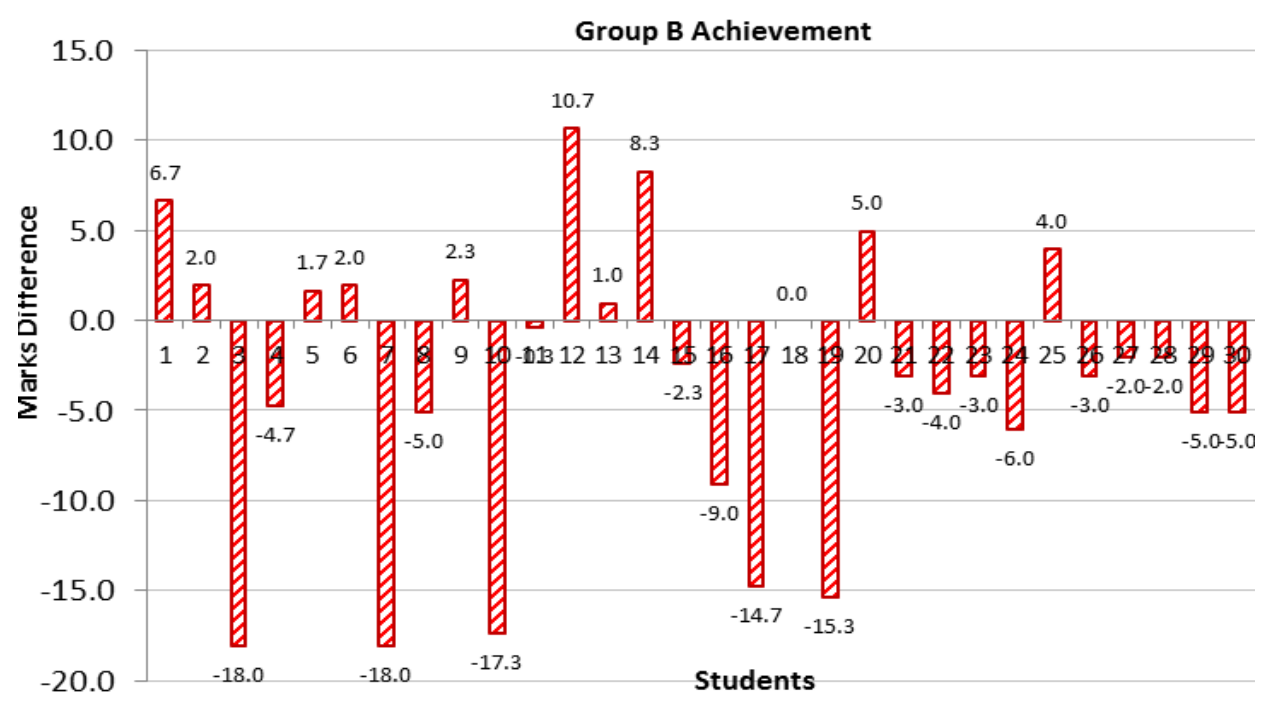

Figure 1(b)

Figure 1 Achievement analysis for course HFC 3042 among a) Group A and b) Group B

Table 1 Indicator of marks within Group A and B

\begin{tabular}{ccccc}
\hline & \multicolumn{2}{c}{$\begin{array}{c}\text { Group A } \\
\text { No of Students \% }\end{array}$} & \multicolumn{2}{c}{$\begin{array}{c}\text { Group B } \\
\text { No of Students \% }\end{array}$} \\
\hline Marks Increase & 27 & 87.1 & 10 & 33.3 \\
\hline Marks Decrease & 4 & 12.9 & 19 & 63.3 \\
\hline No Mark Difference & 0 & 0 & 1 & 3.3 \\
\hline
\end{tabular}

The students' achievement in Jigsaw technique also can be observed through distribution plot from middle semester test and final year examination for course HFC 3042, HFC3022 and HFC3032 as shown in Figure 2.

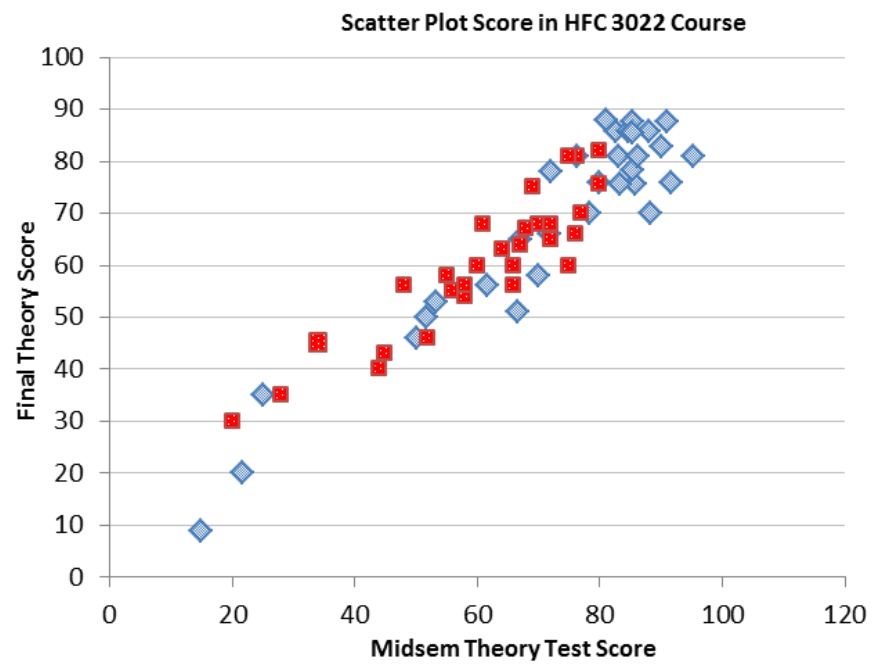

Figure 2(a)

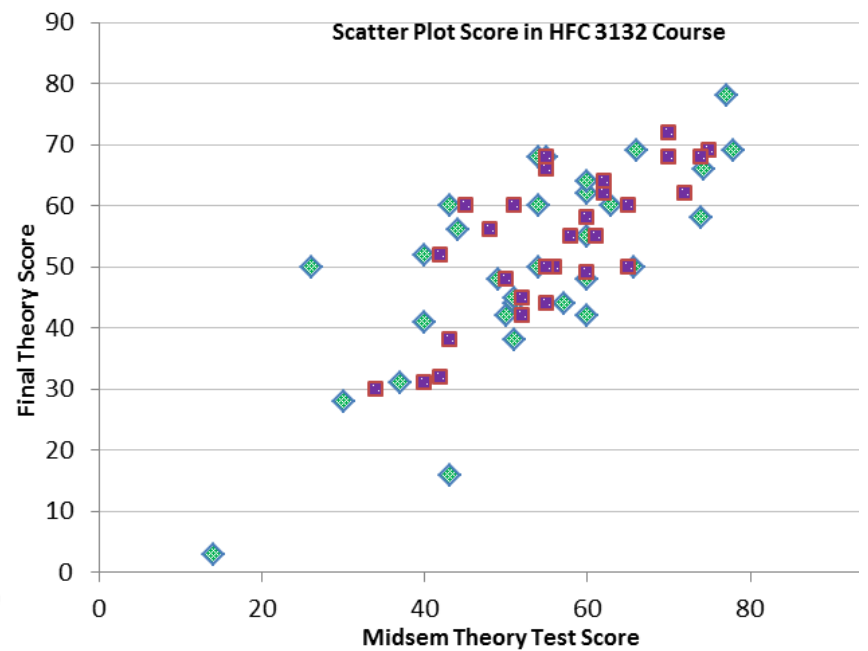

Figure 2(b) 


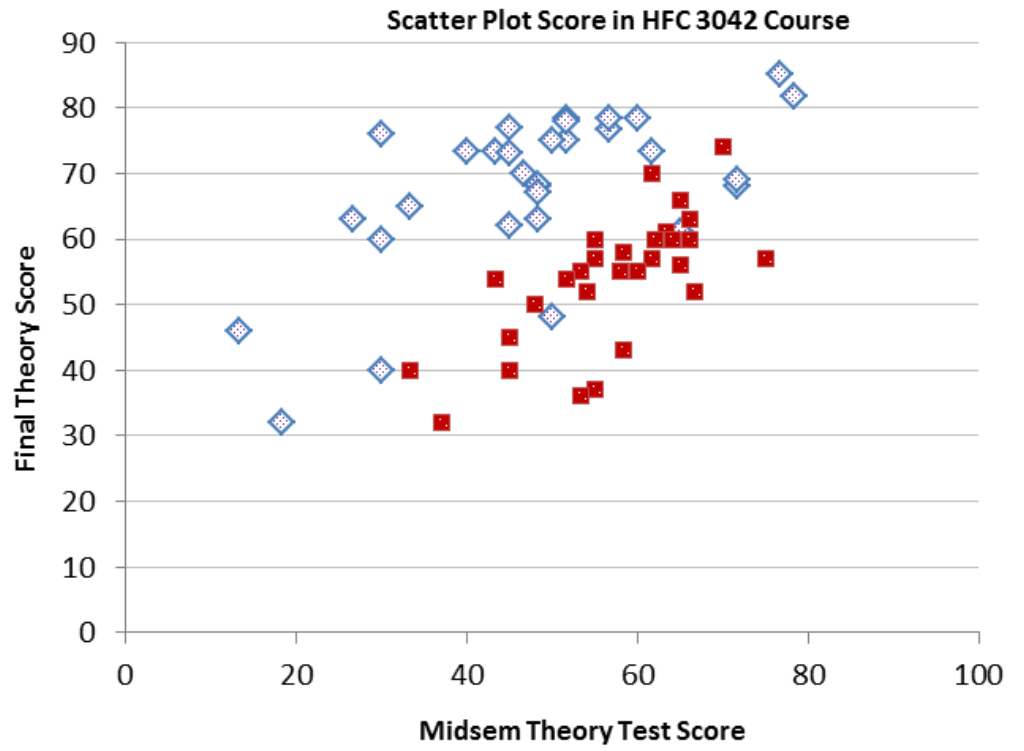

Figure 2(c)

Figure 2 Scatter plot Group A \& B for difference courses a) HFC3022 b) HFC3132 c) HFC3042

Figure 3 shows the one-way Analysis of Variance (ANOVA) from the score flow group A and B for HFC 3042 course.

\section{Means Plots}

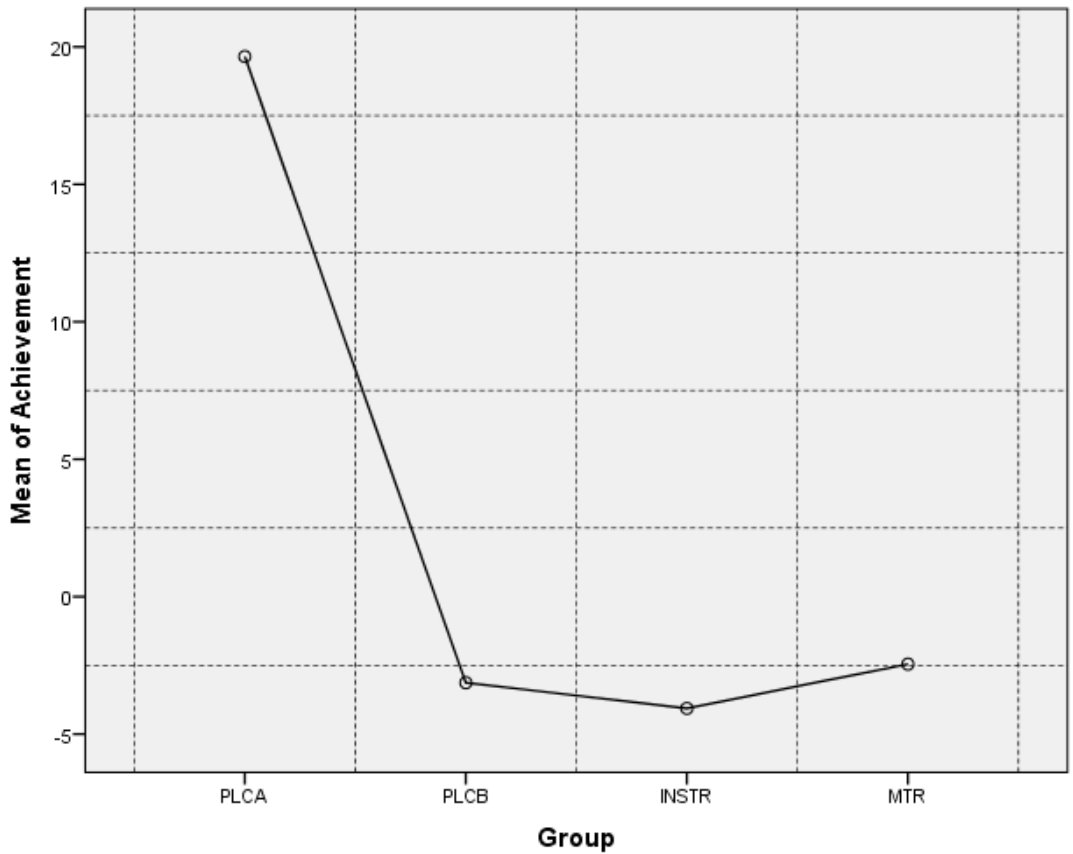

Figure 3 Sample means plot comparison among both groups

This plot compares the sample means among both groups. Means for jigsaw technique group was higher than the traditional group. Table 2 shows ANOVA result for effect of traditional learning and jigsaw learning technique. From this table, null hypothesis (Ho) shows there are no effect on sample population as oppose to the alternative hypothesis (H1) that shows significant effect in the increment of students score on examination for the jigsaw technique group. This can be shown from the small $\mathrm{p}$ value. 
Table 2 Anova result for effect of traditional learning and jigsaw technique

Achievement

\begin{tabular}{cccccc}
\hline & Sum of Square & df & MeannSquare & F & Sig \\
\hline Between Groups & 12163.677 & 3 & 4054.559 & 40.987 & 0.00 \\
\hline Within Groups & 11771.708 & 119 & 98.922 & & \\
\hline Total & 23935.385 & 122 & & & \\
\hline
\end{tabular}

Furthermore, a correlation test was also performed in HFC 3042, HFC3022 and HFC 3132courses. Result from this test is shown in Table 3 and this result support the findings that jigsaw technique gives a positive effect when compared to conventional method (Bolboaca \& Jäntschi, 2006).

Table 3 Correlation test result in HFC 3042, HFC3022 and HFC 3132 courses between mid-term test and final examination

Table 3(a)

\begin{tabular}{llrr}
\hline \multirow{2}{*}{ Test } & \multicolumn{2}{c}{ Test } & \multicolumn{2}{c}{ Final } \\
\cline { 2 - 4 } & Pearson Correlation & 1 & $.944^{* *}$ \\
\cline { 2 - 4 } & Sig (2-tailed) & $\mathrm{N}$ & .000 \\
\cline { 2 - 4 } Final & Pearson Correlation & $.944^{* *}$ & 1 \\
\cline { 2 - 4 } & Sig (2-tailed) & 000 & 31 \\
\cline { 2 - 4 } & $\mathrm{N}$ & 31 & 31 \\
\hline
\end{tabular}

Table 3(b)

\begin{tabular}{llrr}
\hline \multirow{2}{*}{ Test } & \multicolumn{1}{c}{ Test } & \multicolumn{1}{c}{ Final } \\
\cline { 2 - 4 } & Pearson Correlation & 1 & $.727^{* *}$ \\
\cline { 2 - 4 } & Sig (2-tailed) & 31 & .000 \\
\cline { 2 - 4 } & $\mathrm{N}$ & $727^{* *}$ & 11 \\
\hline \multirow{2}{*}{ Final } & Pearson Correlation & 000 & \\
\cline { 2 - 4 } & Sig (2-tailed) & 31 & 31 \\
\cline { 2 - 4 } & $\mathrm{N}$ & & \\
\hline
\end{tabular}

Table 3(c)

\begin{tabular}{llrr}
\hline \multirow{2}{*}{ Test } & \multicolumn{2}{c}{ Test } & \multicolumn{1}{c}{ Final } \\
\cline { 2 - 4 } & Pearson Correlation & 1 & $.625^{* *}$ \\
\cline { 2 - 4 } & Sig (2-tailed) & 31 & .000 \\
\cline { 2 - 4 } & $\mathrm{N}$ & $.625^{* *}$ & 31 \\
\hline \multirow{2}{*}{ Final } & Pearson Correlation & 000 & 1 \\
\cline { 2 - 4 } & Sig (2-tailed) & 31 & 31 \\
\cline { 2 - 4 } & $\mathrm{N}$ & & \\
\hline
\end{tabular}

\section{R-SPQ-2F Score Result}

In addition, deep learning approach in students learning was monitored by using R-SPQ-2F questionnaire before and after treatment. Analysis was carry out by using paired sample T-Test for both groups. 
Table 4 Pre and Post-test score percentage in students' deep learning approach in HFC3042 course for group A and group B.

\begin{tabular}{|c|c|c|}
\hline \multicolumn{3}{|c|}{$\begin{array}{c}\text { A } \\
\text { Deep Approach Score }(\%)\end{array}$} \\
\hline No & Pre & Post \\
\hline 1 & 65.0 & 61.0 \\
\hline 2 & 46.7 & 40.0 \\
\hline 3 & 30.0 & 45.0 \\
\hline 4 & 33.3 & 43.0 \\
\hline 5 & 61.7 & 55.0 \\
\hline 6 & 48.3 & 55.0 \\
\hline 7 & 78.3 & 81.7 \\
\hline 8 & 56.7 & 65.0 \\
\hline 9 & 43.4 & 50.0 \\
\hline 10 & 40.0 & 33.0 \\
\hline 11 & 60.0 & 45.0 \\
\hline 12 & 48.3 & 68.0 \\
\hline 13 & 51.7 & 55.0 \\
\hline 14 & 56.7 & 55.0 \\
\hline 15 & 45.0 & 62.0 \\
\hline 16 & 51.7 & 70.0 \\
\hline 17 & 50.0 & 65.0 \\
\hline 18 & 71.7 & 68.0 \\
\hline 19 & 48.3 & 44.0 \\
\hline 20 & 26.7 & 34.0 \\
\hline 21 & 30.0 & 22.0 \\
\hline 22 & 76.7 & 85.0 \\
\hline 23 & 45.0 & 44.0 \\
\hline 24 & 71.7 & 69.0 \\
\hline 25 & 51.7 & 78.0 \\
\hline 26 & 18.3 & 32.0 \\
\hline 27 & 48.3 & 55.0 \\
\hline 28 & 45.0 & 44.0 \\
\hline 29 & 30.0 & 34.0 \\
\hline 30 & 50.0 & 48.0 \\
\hline 31 & 13.3 & 23.0 \\
\hline
\end{tabular}

\begin{tabular}{|c|c|c|}
\hline \multicolumn{3}{|c|}{$\begin{array}{c}\text { B } \\
\text { Deep Approach Score }(\%)\end{array}$} \\
\hline No & Pre & Post \\
\hline 1 & 33.3 & 40.0 \\
\hline 2 & 55.0 & 57.0 \\
\hline 3 & 75.0 & 57.0 \\
\hline 4 & 61.7 & 57.0 \\
\hline 5 & 53.3 & 55.0 \\
\hline 6 & 48.0 & 50.0 \\
\hline 7 & 55.0 & 37.0 \\
\hline 8 & 60.0 & 55.0 \\
\hline 9 & 51.7 & 54.0 \\
\hline 10 & 53.3 & 36.0 \\
\hline 11 & 58.3 & 58.0 \\
\hline 12 & 43.3 & 54.0 \\
\hline 13 & 65.0 & 66.0 \\
\hline 14 & 61.7 & 70.0 \\
\hline 15 & 63.3 & 61.0 \\
\hline 16 & 65.0 & 56.0 \\
\hline 17 & 66.7 & 52.0 \\
\hline 18 & 45.0 & 45.0 \\
\hline 19 & 58.3 & 43.0 \\
\hline 20 & 55.0 & 60.0 \\
\hline 21 & 58.0 & 55.0 \\
\hline 22 & 64.0 & 60.0 \\
\hline 23 & 66.0 & 55.0 \\
\hline 24 & 66.0 & 60.0 \\
\hline 25 & 70.0 & 55.0 \\
\hline 26 & 58.0 & 55.0 \\
\hline 27 & 54.0 & 52.0 \\
\hline 28 & 62.0 & 60.0 \\
\hline 29 & 37.0 & 32.0 \\
\hline 30 & 45.0 & 40.0 \\
\hline
\end{tabular}

Table 4 shows result of pre and post- test scores for students' deep learning approach in group A and B in HFC3042 course. Table 5(a) and Table 5(b) shows the result of paired t-test for group A and B in deep approach to learning.

Table 5 Result of paired t-test for group A and B in deep approach to learning

Table 5(a)

Paired Samples Statistics

\begin{tabular}{|c|c|c|c|c|c|}
\hline & & Mean & $\mathrm{N}$ & Std. deviation & Std. Error Mean \\
\hline Pair 1 & $\begin{array}{l}\text { Post } \\
\text { Pre }\end{array}$ & $\begin{array}{l}52.5387 \\
48.1742 \\
\end{array}$ & $\begin{array}{l}31 \\
31\end{array}$ & $\begin{array}{l}16.34227 \\
14.84136\end{array}$ & $\begin{array}{l}2.93516 \\
2.84519\end{array}$ \\
\hline
\end{tabular}

Paired Sample Test

\begin{tabular}{|c|c|c|c|c|c|c|c|c|}
\hline \multirow{4}{*}{$\begin{array}{l}\text { Pair } 1 \\
\text { Post -Pre }\end{array}$} & \multicolumn{5}{|c|}{ Paired Differences } & \multirow{3}{*}{$\mathrm{t}$} & \multirow{3}{*}{ df } & \multirow{3}{*}{$\begin{array}{l}\text { Sig. } \\
\text { (2-tailed) }\end{array}$} \\
\hline & \multirow[t]{2}{*}{ Mean } & \multirow[t]{2}{*}{ Std. Dev } & \multirow[t]{2}{*}{ Std. Error Mean } & \multicolumn{2}{|c|}{$\begin{array}{l}\text { 95\% Confidence Interval of the } \\
\text { difference }\end{array}$} & & & \\
\hline & & & & Lower & Upper & & & \\
\hline & 4.36452 & 9.65289 & 1.73371 & .82381 & 7.90523 & 2.517 & 30 & .017 \\
\hline
\end{tabular}

Table 5(b)

Paired Samples Statistics

\begin{tabular}{|c|c|c|c|c|c|}
\hline & & Mean & $\mathrm{N}$ & Std. deviation & Std. Error Mean \\
\hline \multirow[t]{2}{*}{ Pair 1} & Post & 53.8000 & 30 & 9.89392 & 1.80637 \\
\hline & Pre & 56.9300 & 30 & 9.54850 & 1.74331 \\
\hline
\end{tabular}


Paired Sample Test

\begin{tabular}{|c|c|c|c|c|c|c|c|c|}
\hline \multirow{4}{*}{$\begin{array}{l}\text { Pair } 1 \\
\text { Post -Pre }\end{array}$} & \multicolumn{5}{|c|}{ Paired Differences } & \multirow{3}{*}{$\mathrm{t}$} & \multirow{3}{*}{ df } & \multirow{3}{*}{$\begin{array}{l}\text { Sig. } \\
\text { (2-tailed) }\end{array}$} \\
\hline & \multirow[t]{2}{*}{ Mean } & \multirow[t]{2}{*}{ Std. Dev } & \multirow[t]{2}{*}{ Std. Error Mean } & \multicolumn{2}{|c|}{$\begin{array}{l}\text { 95\% Confidence Interval of the } \\
\text { difference }\end{array}$} & & & \\
\hline & & & & Lower & Upper & & & \\
\hline & -3.13000 & 7.56690 & 1.38152 & -5.95553 & -.30447 & $\begin{array}{l}-2 . \\
266\end{array}$ & 29 & .031 \\
\hline
\end{tabular}

The null hypothesis is rejected, since $p<0.05$. There is evidence to suggest that participants experienced statistically significantly deeper learning approach $(\mathrm{p}=0.017)$ when exposed to jigsaw cooperative learning technique (mean $=4.36, \mathrm{SD}=9.65)$ than to traditional learning method (mean $=-3.13$ units, $\mathrm{SD}=1.38$ ). The $95 \%$ confidence interval for the difference is $(0.823,7.905)$.

From the results, a teaching and learning strategy has developed with the use of cooperative learning Jigsaw method to enhanced students' performance and capability towards deeper learning approach.

\subsection{CONCLUSION}

Result implemented from students' data set test through jigsaw learning technique and traditional learning method found obvious difference from students' achievement aspect. Student in group A (Jigsaw) shows high achievement compare to group B (Traditional). This trend can also be seen on students score for courses HFC 3022 and HFC 3132 that used conventional learning method and course HFC 3042 that used jigsaw technique.

From ANOVA test, alternative hypothesis shows there is a positive effect to group A. This clearly can be shown in correlation test that jigsaw technique has a positive effect to learning process compare to traditional method. Furthermore, from Paired sample T-test result found most students perform in Jigsaw technique in cooperative learning tend to improve their deep approach to learning at the end of semester. There is strong evidence $(\mathrm{t}=2.527, \mathrm{p}=0.017)$ that the Jigsaw technique in cooperative learning improves students' deep learning approach.

Therefore, it can be concluded that the jigsaw technique used in cooperative learning can contribute a great improvement toward students' academic achievement.

\subsection{FUTURE WORK}

The approaches that prevail tell us something about the quality of the teaching environment that needs to be taken into consideration. Furthermore, the lack of consistency in the findings highlights the need for more in-depth analysis of the effect of learning strategies on academic performance especially in qualitative way.

\section{Acknowledgement}

The authors wish to thank students who participate in this study and the Centre for Engineering Education (CEE) UTM for supporting this research project.

\section{References}

Ramsden, P. and I. Moses (1992). Associations Between Research And Teaching In Australian Higher Education. Higher Education, 23(3), 273-295.

Heikkilä, A., et al. (2011). Interrelations among University Students' Approaches To Learning, Regulation Of Learning, And Cognitive And Attributional Strategies: A Person Oriented Approach. Higher Education, 61(5), 513-529.

Shaari, B.B.M. and Y.Y. (2012). Jusoh, The Outcome-Based Education (Obe) Curriculum for Electrical Engineering Departments at Malaysian Polytechnics.

Shahri, N., R.A. Rahman, and N.H. Hussain (2014). Student Approach to Learning in Programming Courses among Industrial Mechatronics Engineering Technology Students. in Teaching and Learning in Computing and Engineering (LaTiCE), International Conference on. 2014.

John Biggs 1, D.K.D.Y.P.L. (2001). The Revised Two Factor Study Process Questionnaire: R-SPQ-2F. British Journal of Educational Psychology. 71(133-149), 20.

Shuell, T.J. (1986). Cognitive Conceptions Of Learning. Review Of Educational Research, 56(4), 411-436.

Aini Nazura Paimin, M.A. (2013). Factors Affecting Study Performance of Engineering Undergraduates: Case Studies of Malaysia and Australia. in REES 2013 conference proceedings. Putrajaya Malaysia.

Rowley, J. (2014). Bridging the gap: improving students' learning experience through shifting pedagogical practices in higher education. International Journal of Learning and Development, 4(1), 28-39.

Jacobs, J.C., et al. (2014). Five Teacher Profiles In Student-Centred Curricula Based On Their Conceptions Of Learning And Teaching. BMC Medical Education. 14(1), P.220.

Felder, R.M. And R. Brent. (2004). The ABC's Of Engineering Education: ABET, Bloom's Taxonomy, Cooperative Learning, and so on. in Proceedings of the 2004 American Society for Engineering Education Annual Conference \& Exposition.

Johnson, D.W.J.a.R.T., The Impact of Cooperative, Competitive, and Individualistic Learning Environments on Academic Achievement, 2010, Hattie, J., \& Anderman, E. (Eds.). (in press). International Handbook Of Student Achievement.

Felder, R.M. and R. Brent (2003). Designing And Teaching Courses To Satisfy The ABET Engineering Criteria. Journal of Engineering Education, 92(1), 7-25.

Slavin, R.E. and N.L. (1985). Karweit, Effects Of Whole Class, Ability Grouped, And Individualized Instruction On Mathematics Achievement. American Educational Research Journal, 22(3), 351-367.

Ellis, R. and R. Calvo, (2004). Learning Through Discussions In Blended Environments. Educational Media International, 41(3), 263-274.

Bonwell, C.C. and J.A. Eison (1991). Active Learning: Creating Excitement in the Classroom. 1991 ASHE-ERIC Higher Education Reports: ERIC.

Prosser, M. and K. Trigwell (2001). Understanding Learning And Teaching: The Experience In Higher Education: McGraw-Hill International.

Johnson, D.W. and R.T. Johnson (1993). Creative And Critical Thinking Through Academic Controversy. American Behavioral Scientist, $37(1), 40-53$. 
Aronson, E. (1978). The Jigsaw Classroom. 1978: Sage.

Dr. Spencer Kagan, M.K. (2009). Kagan Cooperative Learning, Kagan Publishing. p. 484.

Johnson, D.W., R.T. Johnson, and M.B. Stanne (2000), Cooperative learning methods: A meta-analysis.

Bolboaca, S.-D. and L. Jäntschi (2006). Pearson Versus Spearman, Kendall's Tau Correlation Analysis On Structure-Activity Relationships Of Biologic Active Compounds. Leonardo Journal Of Sciences, 9, 179-200. 